\title{
HOW THE HOLY GRAIL ENDED UP IN O CEBREIRO, GALICIA
}

\author{
Mathew Kuefler \\ San Diego State University
}

\begin{abstract}
A modern legend says that the Holy Grail was hidden in $\mathrm{O}$ Cebreiro in Galicia. I came upon a possible explanation for it in the course of research into Saint Gerald of Aurillac, a French saint of the tenth century. There was in the Middle Ages a monastic priory dedicated to him there, later abandoned. A miracle was recorded as having happened there, in which a priest, not convinced about transsubstantiation, saw the ritual bread and wine transformed into flesh and blood. When Saint Gerald was mentioned to pilgrims passing through $\mathrm{O}$ Cebreiro, they confused his name-Sant Gral in Galician-with the chalice of the miracle and misidentified it as the Holy Grail-Sant Grial in Galician. The legend was elaborated by Ramón Cabanillas, a modern Galician poet, in a nostalgic manner that recalls Saint Gerald and his medieval biographers: a mix of religious devotion with a martial code.
\end{abstract}

Keywords: Holy Grail, O Cebreiro, Gerald of Aurillac, Ramón Cabanillas, Arthuriana.

\section{CÓMO EL SANTO GRIAL ACABÓ EN O CEBREIRO, GALICIA}

RESUMEN: Una leyenda moderna dice que el Santo Grial fue escondido a O Cebreiro en Galicia. Me encontré con una posible explicación de esta en la realización de investigaciones sobre San Gerardo de Aurillac, santo francés del siglo décimo. Había en la Edad Media un convento dedicado a él, mas tarde abandonado. Fue también un milagro recordado por haber tenido lugar allí, donde un sacerdote, no convencido de la transubstanciación, vio el pan y el vino ritual transforma en carne y sangre. Cuando San Gerardo se mencionó a los peregrinos que pasaran por O Cebreiro, cofundaron su nombre -Sant Gral en gallegocon el cáliz del milagro y lo mal identificaron como el Santo Grial-Sant Grial en gallego. La leyenda se elaboró por Ramón Cabanillas, poeta gallego moderno, 
de manera nostálgica que recuerda San Gerardo y sus biografías medievales: una mezcla de devoción religiosa con un código marcial.

Palabras clave: Santo Grial, O Cebreiro, Giraldo de Aurillac, Ramón Cabanillas, artúricas

The sky, a silken panoply, earth, a flowery carpet, clouds, silver flecks, and every pine tree a lance shaft. Good Friday was gently dawning when Galahad arrived at the mountain valley. Kissed by morning's radiant softness, a shield with its red cross slung across his arm, shod with golden spurs, he held a gleaming sword, and his heart was strong, radiant, and cleansed of sin. He went uphill, while in the wind rang soft and light from an unseen belltower a crystal tinkling. The noble knight went up, in his chivalrous dream, to the miraculous mountain of O Cebreiro-Montsalvat.

A lone hermitage sleeps in its sweet and peaceful cradle, bedded on the crest. There, kneeling alone in silence before the empty altar, Galahad prayed, and surrendered up his sword. And then the hermitage filled with the glow of moonlight and of blond angels dressed in twisting white linen, one with the spear of the Passion, the other swinging a censor, soldiers of the Lord, both with the sign of a red cross on their breast and a white lily in their hand.

From his lips blooms a psalm, the fruit of his prayer, and, transported by divine love, Galahad raises his head. His eyes behold the miracle! Upon the altar table, glowing with light, gleams the chalice of the Holy Grail. A clamor of bells breaks out, the earth flowers with roses, and the dove of the new covenant comes down from heaven to renew the mystery, holding the green branch of peace. Around it, in a circle, twelve stars shine, and remain, hovering quietly above the Holy Grail ${ }^{1}$.

1. Cabanillas, Ramon, "O cabaleiro do Sant Grial," trans. Jason Preater, available online at http://menemenetekel.wordpress.com, with slight revisions. All other translations in what follows are my own. For the original see Cabanillas, R., Obras completas, ed. X. Alonso Montero, vol. 3. Madrid, 1979, pp. 380-87; quotation at pp. 386-387: "O ceo pallio de seda, / alfombra florida o chan, / as nubes flecos de prata / e cada pino un varal, / o día do Viernes Santo / ten un maino crarexar / cando á valgada dun monte / foi chegado Galahaz. / Bicado da recendente / soavidade da mañán, / o escudo da cruz vermella / cinguido polo brazal, / espora de ouro calzada, / luminosa espada na man, / o corazón esforzado, / aceso e limpo de mal, / costa arriba, mentras zoa / no vento maino e levián / de segreda campaíña / o tanguido de cristal, / rube o nobre cabaleiro, / no seu soño a cabalgar, / a montaña milagreira do Cebreiro-Monsalvat. / Como un corazón aberto, / berce de dozura e paz, / dorme unha ermida acochada / do cume na soedá. / Alí, senlleiro, en silenzo, / diante do valeiro altar, / arelante, 
These words come from the Galician poet Ramon Cabanillas and were written in 1926. That isolated church at O Cebreiro still stands, looking very medieval although in fact much altered since the Middle Ages, and local legend still purports that the Holy Grail appeared there (see figures 1 and 2)2.

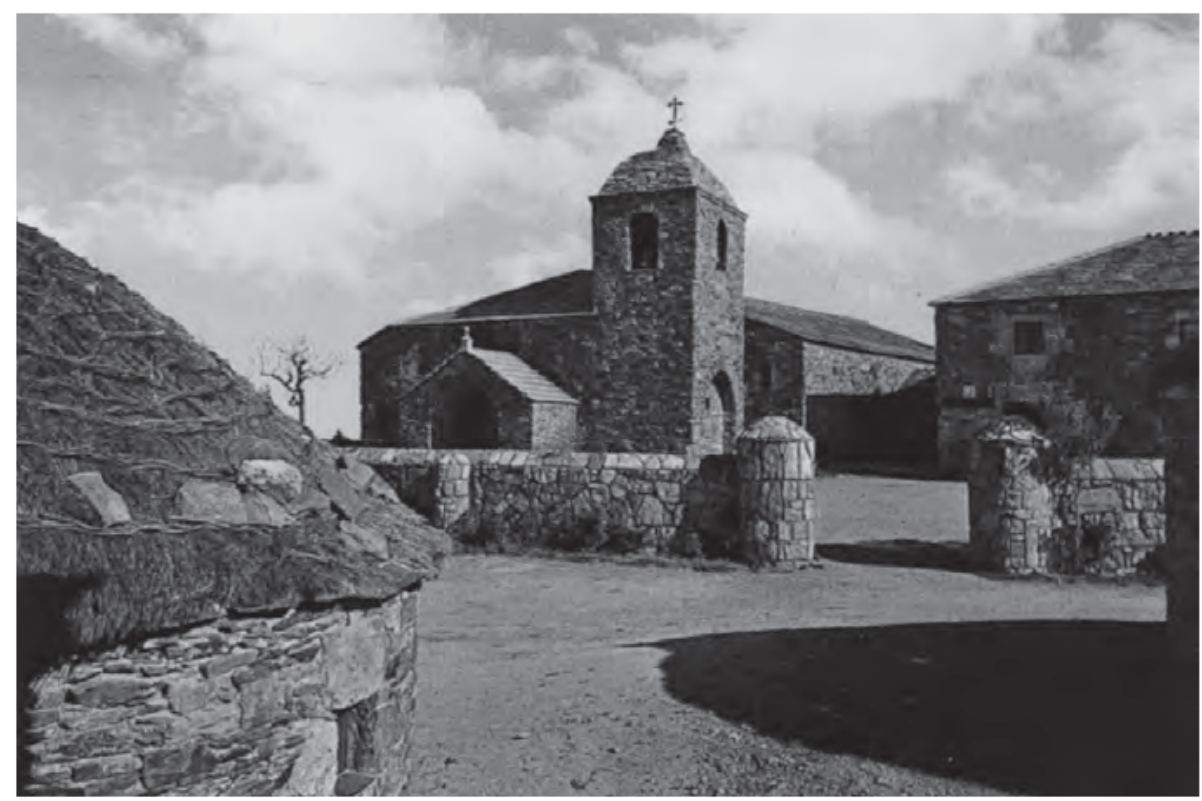

Figure 1. The modern church at O Cebreiro, exterior. Fotographia de Fama Vigo S.L.

do xoellos, / rende a espada Galahaz. / A tal intre, énchese a ermida / dun resprandor de luar / e de anxos roibos, vestidos / de branco liño torzal; / un coa lanza da Pasión, outro o incensario a voltar, / lexionarios de El Señor, / todos levan por siñal / unha cruz roxa no peito / e un lirio branco na man. / Dos beizos a fror, o salmo / do seu degaro a pregar, / trasposto de amor diviño / alza a frente Galahaz. / ¡Seus ollos ven o miragro! / ¿Encol da ara do altar, / á luz infinda, relumba / o cáliz do SANT GRIAL! / Estala un cramor de sinos, / frorece en rosas o chan / e a Pomba de Renacencia, o Misterío a renovar, / desce do ceo portando / a verde ponla da paz. / ¡Ó seu arredor, en circo, / doce estrelas a brilar, / fican, voando quediño, / enriba do SAN GRIAL!"

2. See Inventario artístico de Lugo y su provincia, vol. 2, Campo-Estraxiz. Madrid, 1975, pp. 173-174 for a description of the modern church. It is noted, for example, that the overall orientation of the church has been reversed. See also Frontón, Isabel, El arte románico en el Camino de Santiago: El arte de viajar. Madrid, n.d., p. 189, on archeological evidence about the medieval church; and Valiña Sampedro, Elias, El camino de Santiago: Estudio historicojuridico. Lugo, 1971, pp. 172-173, on the renovations. 


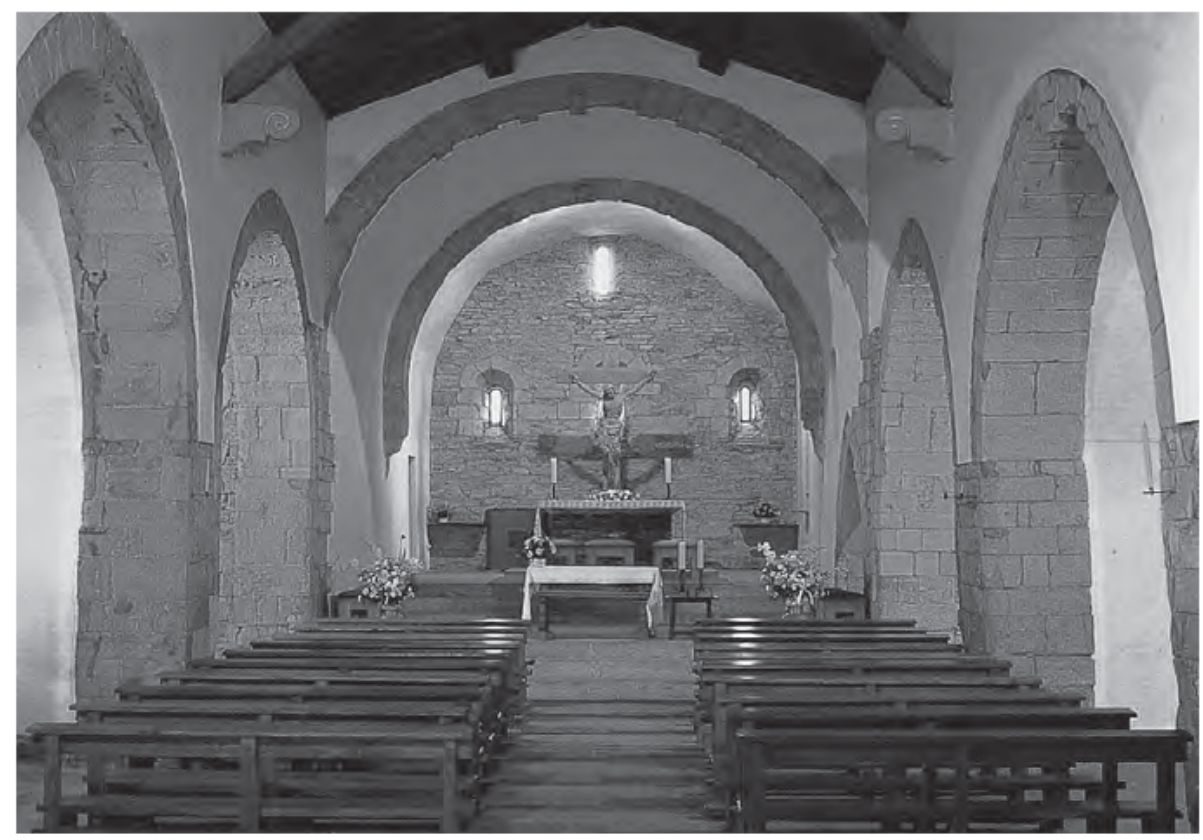

Figure 2. The modern church at O Cebreiro, interior. Fotographia de Fama Vigo S.L.

O Cebreiro (El Cebrero in Castilian Spanish) is an unassuming village in the highlands of Galicia (see figure 2). It lies along the medieval and modern pilgrimage route to Santiago de Compostela, indeed, it is the highest point in that route save the passes through the Pyrenees, at some 1300 meters above sea level. It takes its name from the Latin Februarius -a name chosen, I like to imagine--, because February lasts so much longer there than anywhere else.

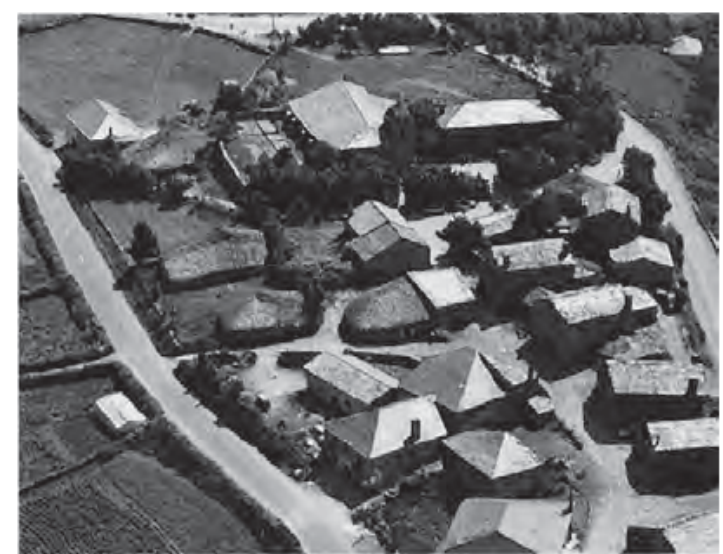

Figure 3. The modern village of O Cebreiro, Galicia. Fotographia de Fama Vigo S.L.

It was presumably because of the difficulty of that ascent -the last great climb for pilgrims on their way to Compostela, although their destination was still a hundred and fifty kilometers distant- and the possibility that snows might strand those travelers or that some might be too weak to continue without rest, that King Alfonso 
VI of León granted the lands at the top of the mountain in 1072 to a group of French monks. (He and other Spanish monarchs planted a number of French monasteries all along the pilgrimage route to Compostela in the eleventh and twelfth centuries) ${ }^{3}$.

Those French monks belonged to the monastery of Aurillac, in the Auvergne region of south-central France (it is, in fact, a mountainous region much like the area around $\mathrm{O}$ Cebreiro). That monastery had been founded at the end of the ninth century by the nobleman Gerald, who donated his lands for the purpose; the monks returned the favor by remembering Gerald as a saint and rededicating the monastery to Gerald himself within a century of his death ${ }^{4}$.

Gerald's rise to sanctity is an interesting one. He is one of the first male saints who achieved holiness not by abandoning his position and wealth for the cloister or cathedral but simply by doing good as a layman; his medieval hagiographer, who was clearly aware of Gerald's novelty in this regard, included an episode in which Gerald revealed his desire to become a monk to a bishop and friend, who persuaded

3. The best source for information on the history of O Cebreiro is Valiña, El Camino de Santiago, pp. 133-175; see also Alvilares, J., El Cebrero. Santiago de Compostela, 1956. The speculations of Stopford, J., "Some Approaches to the Archeology of Christian Pilgrimage," World Archeology 26 (1994), pp. 57-72, are useful in thinking of the geography of pilgrimage; she notes, for example, that medieval hospices were often built at the most difficult points on pilgrimage routes as aids to pilgrims. On this point for another site see also Ruiz de la Peña Solar, J. I., Foncebadón y la asistencia hospitaliaria en los puertos de las montañas Astur-Galaico-Leonesas durante la edad media. Astorga, 2003. For more on monasticism in medieval Galicia, see Andrade Cernadas, J. M., Monxes e mosteiros na Galicia medieval. Santiago de Compostela, 1995; for more on French monastic settlements in Iberia, see Segl, P., "Die Cluniacenser in Spanien: Mit besonderer Berücksichtigung ihrer Aktivitäten im Bistum León von der Mitte des 11. bis zur Mitte des 12. Jahrhunderts." Constable, Die Cluniacenser in ihrem politisch-sozialen Umfeld. Münster, 1998, pp. 537-558; or Perrel, J., "Le bas Limousin et le chemin de Compostelle," Bulletin de la Société des Lettres, Sciences et Arts de la Corrèze 67 (1963), pp. 49-54.

4. The best history of the monastery of Aurillac is still Bouange, G.-M.-F., Saint Géraud d'Aurillac et son illustre abbaye. Aurillac, 1881.

5. On Saint Gerald's unique sanctity, see Airlie, S., "The Anxiety of Sanctity: St. Gerald of Aurillac and his Maker." Journal of Ecclesiastical History 43 (1992), pp. 372-395; Baker D., "Vir Dei: Secular Sanctity in the Early Tenth Century," Popular Belief and Practice: Papers Read at the Ninth Summer Meeting and the Tenth Winter Meeting of the Ecclesiastical History Society. Cambridge, 1972, pp. 41-53; Barthélemy D., Chevaliers et miracles: La violence et le sacré dans la société féodale. Paris, 2004, chap. 2; Lauranson-Rosaz C., "La vie de Géraud d'Aurillac: Vecteur d'une certaine conscience aristocratique dans le midi de la Gaule." Guerriers et moines: Conversion et sainteté aristocratiques dans l'occident médiéval (IXe-XIle siècle. Antibes, 2002, pp. 157-181; Lotter F., "Das Idealbild adliger Laienfrömmigkeit in den Anfängen Clunys: Odos Vita des Grafen Gerald von Aurillac." Benedictine Culture, 750-1050. Louvain, 1983, pp. 76-95; Noble T., "Secular Sanctity: Forging an Ethos for the Carolingian Nobility." Lay Intellectuals in the Carolingian World. Cambridge, 2007, pp. 8-36; Rousset P., “L'idéal chevaleresque dans deux Vitae clunisiennes," Études de civilisation médiévale (IXe-XIle siècles): Mélanges offerts à Edmond-René Labande. Poitiers, 1974, pp. 623-633. 
him instead to remain in the world. So Gerald treated his peasants well, judged local disputes with impartiality, and engaged in warfare only in limited ways ${ }^{5}$.

By the late eleventh and early twelfth centuries, the monastery at Aurillac held properties not only in Auvergne but also scattered in priories across southern France and a few beyond, including a handful in Catalonia and in Galicia, among which should be counted $\mathrm{O}$ Cebreiro ${ }^{6}$. It may have been difficult for the mother-house in Aurillac to staff or supervise so far distant a site: the historical record is scanty, but there is the solitary record of a dispute in 1188 between the prior of $O$ Cebreiro and that of Villafranca del Bierzo, a daughter-house of Cluny, over property at Pereje that both claimed; in the end, the prior of O Cebreiro -clearly the loser in this struggleagreed to demolish a church that he had just completed on the site?

The monastery's fortunes did not last, however. Tensions between its monks and the inhabitants of the town of Aurillac that had grown up around it festered and then erupted in 1233, when townsmen sacked its buildings ${ }^{8}$. Even after peace was restored and rights were granted to the town, though, the monks of Aurillac began selling off their distant properties and abandoning their priories, among them, that at $\mathrm{O}$ Cebreiro. When Ferdinand and Isabella visited the spot on their pilgrimage to Compostela in 1486, the church and other buildings were in ruins. So they transfered control of the properties to monks at Valladolid 9 .

We seem a long way from the Holy Grail. But the visit to O Cebreiro by Ferdinand and Isabella was also the occasion for the first recorded instance of a eucharistic miracle said to have happened there at an earlier date. The fact that no specific year was ever recalled for this miracle should be the first clue that it may never have happened; in fact, it seems suspiciously close to the miracle of Bolsena in central Italy that is said to have taken place in 1263 and that helped to establish the Catholic feast of Corpus Christi. Notwithstanding, the miracle at O Cebreiro was given papal approval in 1487, the year following Ferdinand and Isabella's visit. In both miracles,

6. On the monastic possessions of Aurillac in Galicia, see Valiña, op. cit., pp. 133-75; on those in Catalonia, see Beaufrère, A., "San Grau: Le bon comte Géraud d'Aurillac et la Catalogne." Revue de la Haute Auvergne 57 (1995), pp. 5-38. More generally on the geographical dispersion of the cult of Saint Gerald, see Moulier, P., ed., Sur les pas de Géraud d'Aurillac en France et en Espagne. Saint-Flour, 2010, pp. 119-200.

7. Generally on what survives of the medieval history of O Cebreiro, see Valiña, op. cit., pp. 133-57; on this dispute in particular, see pp. 104-10. On the properties attached to $\mathrm{O}$ Cebreiro in the Middle Ages see Delgado Gómez, J., El camino francés de Santiago en su tramo lucense. Santiago de Compostela, 1993, pp. 33-36.

8. On these events see Grand, R., Les "paix" d'Aurillac: Étude et documents sur I'histoire des institutions municipales d'une ville a consulat (XIle-XVe siècle). Paris, 1901.

9. The history of the site is recounted by Vázquez de Parga, L., et al., Las peregrinaciones a Santiago de Compostela, 3 vols. Pamplona, 1992, vol. 2, pp. 313-318. Most accounts follow roughly the same outline and provide the same details.

10. On this miracle, see Arias, P., "El santo milagro del Cebrero y los abades del monasterio de San Benito el Real de Valladolid," Boletín de la comisión de monumentos de Lugo 31-32 (1949), pp. 316-318; see also Valiña, op. cit., pp. 151-157. 
a priest sceptical of the doctrine of transsubstantiation was stunned into conviction when the bread and wine turned into real flesh and blood at the moment of consecration $^{10}$.

At $\mathrm{O}$ Cebreiro, two artifacts lent support to this miracle. The first is a statue of the Madonna and Child, which is said to have bent forward to observe the miracle as it happened. And, indeed, there is in the modern church such a statue, leaning precariously forward. She is called Santa Maria la Real, and the modern church is dedicated to her. (See figure 4 . The source of this epithet is unknown, but there are many images of the Virgin called "la Real" along the pilgrimage route to Compostela) ${ }^{11}$. The second artifact is a chalice: the one, in fact, that is said to have been involved in the eucharistic miracle. Most mentions date both statue and chalice to the twelfth century. It is true that the Madonna resembles others of the twelfth

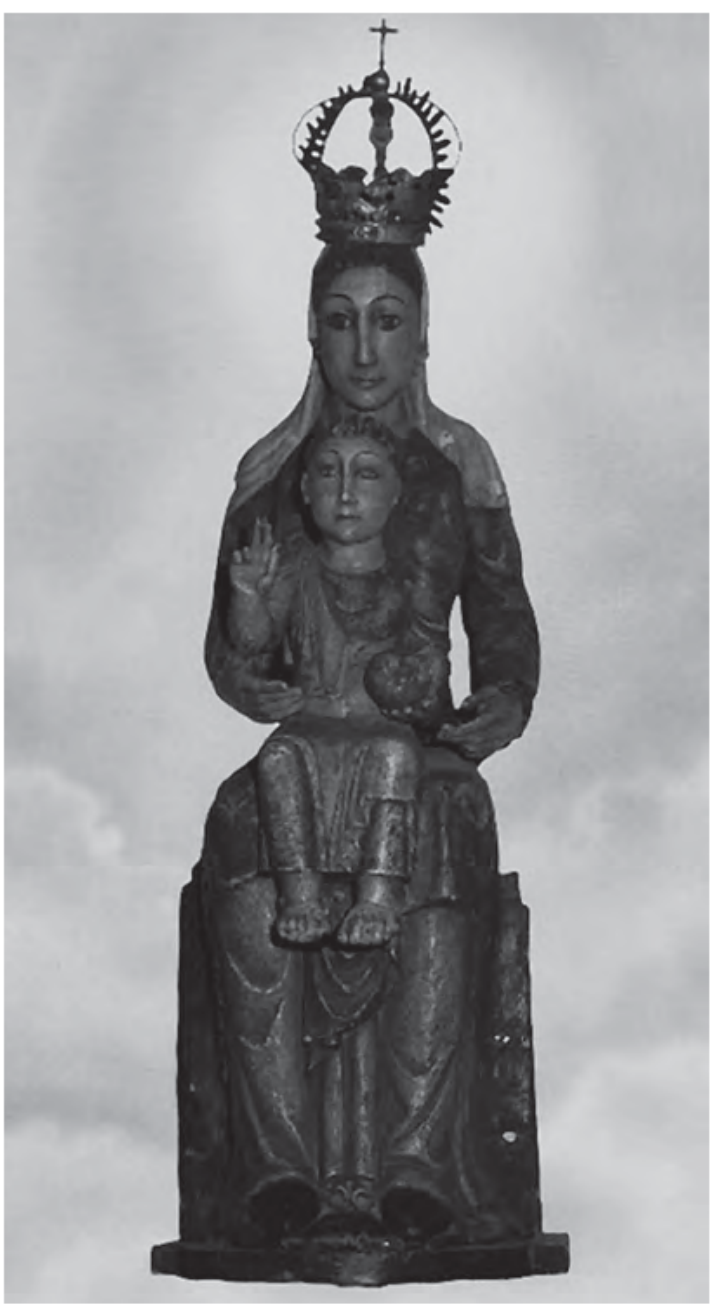

Figure 4. Santa Maria la Real, O Cebreiro. Fotographia de Fama Vigo S.L. century crafted especially in southern France, although the origins of both it and the chalice have been lost. It is probably only coincidence that there is also a legend about a chalice at Aurillac, said to have been given to Saint Gerald himself by the pope and claimed to have once belonged to Saint Peter, but it was already said to have been lost by the

11. See Cuende, M., and Izquierdo, D., La Virgen María en las rutas jacobeas: Camino francés. Santiago de Compostela, 1997, 76-82. 
early seventeenth century when the legend about it was first recorded ${ }^{12}$. The chalice at $\mathrm{O}$ Cebreiro bears two inscriptions: below, "In the name of the Lord Jesus Christ and of the Blessed Virgin Mary," and above, "By this covenant is consecrated that through which life is obtained for all" (see figure 5) ${ }^{13}$.

It seems that someone, shown the chalice of the miracle at O Cebreiro, believed it to be the Holy Grail. If it were the same chalice as that believed once to have belonged to Saint Peter, that misremembering would be all the more plausible. Even if not, however, the chalice had assumed a central role in local devotion at the very time that Saint Gerald's memory was being lost. We call him Saint Gerald, in modern French he is Saint Géraud, and in modern Castilian Spanish he is San Giraldo. But most in the Middle Ages would have called him Sant Guiral, his name in the Occitan language spoken at Aurillac and throughout southern France ${ }^{14}$. And in Galicia he was known as Sant Gral. Is it really that hard to imagine that some, shown a chalice they were encouraged to revere in a

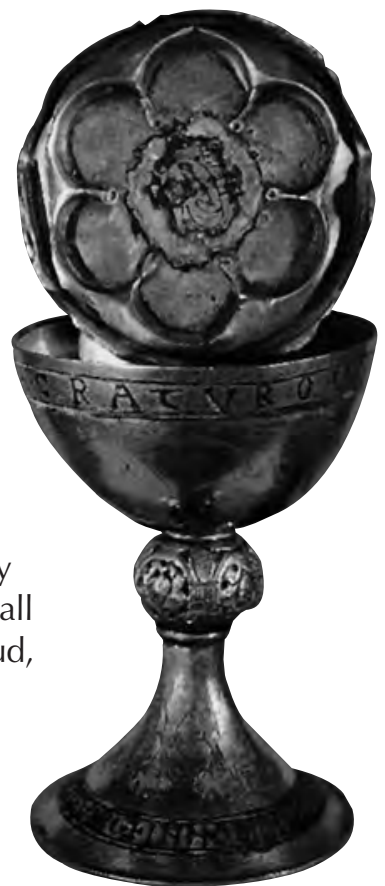

Figure 5. "Chalice of the miracle, O Cebreiro. Fotographia de Fama Vigo S.L." church named for Sant Gral, about whom they had never heard, mistook it for the Holy Grail (Sant Grial in the Galician language)?

Unfortunately, we don't know how early this opinion began that placed the Holy Grail at O Cebreiro. The first discussions its placement in Galicia come only from the turn of the twentieth century ${ }^{15}$. Most likely they depend much on the romantic revival of Arthurian tales, and especially to Richard Wagner's opera Parsifal, first staged in 1882, where the Grail was said for the first time to have been

12. Dominique de Jésus [Viguier, G.], Histoire paraenetique des trois saincts protecteurs de Haut Auvergne. Paris, 1635, 11.6.

13. "IN NOMINE DOMINI IESU XPISTI ET BEATE MARIE VIRGINIS" and "HOC TESTAMENTO SACRATUR QVO CUNTIS VITA PARATUR."

14. On the identification of Saint Guiral and Sant Grau (Gerald's name in Catalan) with Saint Gerald of Aurillac, see Moulier, P., "De Saint Géraud à Saint Guiral, et retour: Acclimatation, appropriation, oblitération d'un culte," Sur les pas de Géraud, pp. 91-111.

15. See Arias Sanxurxo, X., "Sobre a localización xeográfica do Sant-Grial," Arquivos do Seminario de estudos galegos 1 (1927), pp. 129-138. Arias notes earlier brief comments, the earliest of which comes from 1905; he attempts to reconcile Wolfram von Eschenbach's description of the hiding of the Grail with Galician geography. 
hidden at a place called Monsalvat, otherwise unidentified, but located somewhere in the north of Spain. That notion likely appealed to many. Already in 1899, for example, the Galician novelist Emilia Pardo Bazán published a novella titled "El santo Grial," in which a modern gentleman receives a vision of the Grail (although O Cebreiro is not mentioned; indeed, his vision takes place in a modern casino) ${ }^{16}$.

Ramon Cabanillas was apparently the first to connect O Cebreiro specifically with the Holy Grail, at least in writing, in the 1926 poem that I quoted above, titled "O cabaleiro do Sant Grial." It formed part of a poetic trilogy that also places the discovery of the sword Excalibur and the death of King Arthur in Galicia. Mercedes Fernández Dans believes that he derived his material from the version of the Grail story as told by Pseudo-Boron in the early thirteenth century, whose text had been translated into Castilian in 1907-although he borrowed freely-, adding new elements, including the mention of O Cebreiro ${ }^{17}$. I have been able to find the same identification in only two Galician writers after Cabanillas, Álvaro Cunqueiro Mora and Leandro Carré Alvarellos, both in accounts that seem clearly derived from him ${ }^{18}$.

To be sure, the idea that the Grail might be found at O Cebreiro contradicted other contemporary placements of it elsewhere, especially at Montserrat outside Barcelona or at Valencia. But Juan Miguel Zarandona has persuasively argued that whether for Galician, Catalan, or Basque writers of the early twentieth century, all of whom localized the Grail as hidden within their borders, it served as a potent symbol of regional autonomy even as it provided opportunities to retell a long admired legend in the languages that were then being newly revived ${ }^{19}$. Galicia

16. Pardo Bazan, E., "El santo Grial," Obras completas, vol. 1. Madrid, 1973, pp. 1263-1265.

17. Fernández Dans, M., "Os persoaxes de 'O cabaleiro do santo Grial' e os das aventuras de Galaad na 'Queste' francesa," Grial 54 (1976), pp. 465-475. She does not dicuss the addition of $\mathrm{O}$ Cebreiro as she is interested in the changes in characters in the legend and in their personalities.

18. The one, first published in 1965, is Cunqueiro Mora, Á., "La flor de los caminos," Viajes imaginarios y reales. Barcelona, 1986, pp. 5-57, quotation at 56: "Y pronto los montes gallegos, con el Cebrero del Santo Grial, y Parsifal y don Galaz acariciando con las plumas se sus yelmos las ramas verdes de los alcapadres por caminos donde el corzo y el lobo se saludan." The other, first published in 1977, is Carré Alvarellos, L., Las leyendas tradicionales gallegas. Madrid, 1999, pp. 131-133 (on the eucharistic miracle at O Cebreiro, although this section is titled "El santo Grial del Cebrero"), pp. 342-347 (on Galahad's search for the Holy Grail, titled "Galaaz y el santo Grial," a paraphrase of Cabanillas' poem, and including mention of O Cebreiro at 347). I am grateful for the mention of these authors by Juan Miguel Zarandona, "From Avalon to Iberia: The Contemporary Literary Returns of Kind Arthur in the Languages of Spain: An Annotated Listing of Arthurian Spanish Literature in the 19th, 20th, and 21st Centuries," online at: http://www.lib.rochester.edu/camelot/acpbibs/spanbib.htm. See also his "La literatura artúrica española, ibérica e iberoamericana contemporánea: Neo-medievalismo cultural, literatura comparada y tradicción literaria." Mil Seiscientos dieciséis 12 (2006), pp. 107-118.

19. Juan Miguel Zarandona, "El impacto de la literatura artúrica en la construcción de identidades culturales y nacionales periféricas en la España contemporánea: Cataluña, Galicia y el País Vasco." Linguistica y literatura 51 (2007), pp. 217-230. 
had perhaps the best claim of any of these to be heir to a Celtic past, and the Arthurian myths provided for Cabanillas (who was among the first at all to write in the Galician language) an ancient and uniquely regional heritage that was only too happily avowed ${ }^{20}$.

Curiously enough, in his retelling of the search for the Holy Grail, Cabanillas returned to many of the themes that had inspired devotion to Saint Gerald in the first place, specifically, the potent mix of piety, manly beauty, and martial prowess found in Galahad. (Cabanillas was not alone in giving the Grail vision to Galahad, although Perceval is the more common choice of Grail hero ${ }^{21}$.) Cabanillas repeatedly refers to him as "Galahad, the Hoped-for-One [O Esperado]." The poem describes him as "without sword or helmet, without spurs or shield, he had the grace of a boy, but the deportment of a man; like spikes of wheat his golden hair, his heart like roses, his azure eyes, and the holy cross, red like an open wound, adorned the whiteness of his cloak over his chest" 22 . This part of the poem concludes: "To such a one as him it will be given to conquer the Holy Grail, who begins, his heart pure and cleansed of $\sin ^{\prime \prime 2}$.

Gerald had offered the same compelling blend of virtues to his contemporaries. According to the longer version of his vita, he had waged war reluctantly, only to protect the innocent from the predations of the wicked, after peaceful alternatives had failed, and, even then, ordering his men to put their swords away and fight only with their lances ${ }^{24}$. Thus did he maintain his "piety even in the midst of fighting" 25 . Clearly it was inconvenient for a saint to be depicted as engaged in battle, however halfheartedly, and that vita continues:

20. There are a range of claims to being the site where the Grail was hidden, virtually all of which appeared in the early twentieth century, especially in the west of England and in Wales, although there is also a Genoese claim to it, which seems to be the only claim older than the twentieth century. See Wood, J., "The Holy Grail: From Romance Motif to Modern Genre," Folklore 111 (2000), pp. 169-190, at 185.

21. Ibid., 175.

22. Cabanillas, "O Cabaleiro," 381: "Galahaz, o Esperado. / Sin espada nin casco, sin espora ni escudo, / ten a gracia dun neno, / mais o porte barudo, / como espigas do trigo os cabelos doirados, / a cor como de rosas, os ollos azuados / e a cruz sagra, vermella como aberta ferida, / na brancura do traxe, sobre o peito garnida."

23. Ibid., 382: "A aquel Ile será dado conquerir o SANT GRIAL / que o corazón enxergue puro e limpo de mal."

24. Vita sancti Geraldi Aureliacensis. Brussels, 2009, 1.8: "mucronibus gladiorum retro actis, hastas inantea dirigentes pugnarent." The command is an unusual one: perhaps the hagiographer meant that Gerald instructed his men to drive the enemy away with their lances rather than to wound them with their swords. I do not refer to the authorship of this vita because although the work is traditionally ascribed to Odo of Cluny and the early tenth century, including in Bultot-Verleysen's recent critical edition of the text, I believe it was an early eleventh-century forgery, and that Odo authored a briefer and less well known version of Gerald's vita. I will argue this point at length in a forthcoming article, "Dating and Authorship of the Writings about Saint Gerald of Aurillac to be published in Victor in 2013".

25. Ibid., 1.8: "pietas in ipso praeliandi articulo." 
"No one should be disturbed at all that a just man ever made use of fighting, which seems to be incompatible with religion. Indeed, no one whatsoever who will have considered the case with a fair set of scales will esteem the glory of Gerald to be obscured in this point ${ }^{26}$ ". That his hagiographer spent so much time defending Gerald on this score shows how unconventional his depiction of a saint who used violence was, it seems to me, and how deeply uncomfortable he was in trying to accept this possibility, and perhaps also how anxious he was that readers or listeners might refuse to believe in Gerald's holiness because of it ${ }^{27}$. Still, the justification of violence in the service of good lies also at the core of the Arthurian heroic ideal.

In the same account, not long after, Gerald's beauty is also admired: "He was of a medium height and completely, one might say, bien formé, that is, well formed. And while his beauty had adorned each and every part of his body, he had a neck so white and glorious -almost as if it were the epitome of how a neck should appear- that you could scarcely imagine having seen another quite so graceful. Of course, the elegance of his body was further decorated by the loveliness of his mind ${ }^{28}$. The appeal of masculine beauty is also fundamental to the Arthurian hero.

The decline and fall of the monastery of Aurillac -it was closed in the sixteenth century after a series of scandals- lost for Gerald those who would have remained his greatest advocates. Furthermore, while Gerald's hagiographer had explored the awkwardness of violence in the Christian life through his example, by the later Middle Ages it did not loom so large a problem: not, by any means, that violence had ceased to happen, but its usefulness in Christian causes had been firmly established. New and more hotly burning questions arose: the balance between poverty and wealth, the competing demands of logic and faith, the new martydoms of the Reformation and Counter-Reformation, and on these issues Gerald had nothing to say.

It would take a modern nostalgia for the Middle Ages, willing to overlook the brutality and superstitions of the era (or, perhaps, hoping to ignore the brutality

26. Ibid., 1.8: "Nemo sane moueatur quod homo iustus usum preliandi, qui incongruus religioni uidetur, aliquando habuerit: quisquis ille est, si iusta lance causam discreuerit, ne in hac quidem parte gloriam Geraldi probabit obfuscandam."

27. On the complicated intersections of violence and sanctity in this period, see Barthélemy, Chevaliers et miracles; Bull, M., Knightly Piety and the Lay Response to the First Crusade: The Limousin and Gascony, c. 970-c. 1130. Oxford, 1993; Edrman, C., Die Entstehung des Kreuzzugsgedankens. Stuttgart, 1935; and Allen Smith, K., War and the Making of Medieval Monastic Culture. Woodbridge, UK, 2011.

28. Vita sancti Geraldi Aureliacensis, 1.12: "Geraldus igitur erat staturae mediocris et totus, ut dicitur, euformis, id est, bene formatus. Et cum unumquodque membrum sua pulcritudo compsisset, collum tamen ita candidulum et quasi ad normam videndi decusatum habebat, ut vix aliud tam graciosum vidisse te putares. Eleganciam sane corporis venustas animi decorabat." 
and superstitions of its own modern age), to resuscitate Gerald at O Cebreiro in the guise of Galahad. Ironically, Gerald's hagiographer had foretold such a fate: "Since a dead man quickly disappears from our hearts and we immediately give him over to oblivion, and since we do not remember the reward that remains to the saints through their deeds, we become wickedly apathetic about those actions that we should imitate. For that reason perhaps God deigns to work miracles from time to time, so that... we might learn to grow strong in those things that should be imitated"29.

I cannot offer so profound a lesson to be learned from the strange metamorphosis of Saint Gerald into either the Holy Grail or its pursuer. Instead, I'll say simply and much more prosaically that Gerald is back at O Cebreiro: a hostel constructed in the 1960s for modern pilgrims to Compostela is now named for him, thanks to a historically-minded parish priest ${ }^{30}$. The Grail also survives there, still hidden, its mysterious presence declared to the pilgrims as they pass through. The only conclusions I can offer are slight ones. The story of O Cebreiro provides a wonderful occasion to reflect on the weird transformations of local memories. In particular, it offers us a glimpse at how a sacred landscape was redefined and reinvigorated through time, and how the content of the holy evolved, even shifted, so as to preserve its relevance for the modern age -or possibly its very presence in a desacralized era- despite the loss of historical accuracy. As such, this minor legend deserves its small place in the larger story that is the recasting of medieval memories in modern times.

I would like to thank Michael Ryan, Lisa Nalbone, and the other participants of the Twenty-Sixth Annual International Conference for Studies in Medievalism in Albuquerque, Nw Mexico in October 2011, and also to the editor of Brocar and the anonymous reader for the journal for their assistance with this article. I am also grateful to Fama Vigo S.L. for their kind permission to reprint the images included here.

29. Ibid., 3.12: "Sed quia mortuus cita recedit a corde, protinus hoc oblivioni tradimus et, non recogitantes mercedem quae sanctis eius operibus restat, ad haec imitanda male torpescimus. Ob hoc itaque miracula quae foris ad tempus fiunt operari dignatur, quatinus... ad haec imitanda convalescere studeamus."

30. The priest was Elias Valiña Sampedro, author of El Camino de Santiago, op. cit. 